\title{
Health Technology Assessment in Latin America and the Caribbean
}

\author{
David Banta \\ Professor Emeritus, University of Maastricht
}

The Pan American Health Organization (PAHO), Regional Office of the World Health Organization $(\mathrm{WHO})$ for the Americas, has tried to promote health technology assessment (HTA) in Latin America for 25 years. A certain awareness of HTA developed in several countries because of these efforts. In the late 1990's, there was a strong movement for health reform in Latin America, and HTA became part of that movement. Countries that now are actively institutionalizing HTA include Brazil, Mexico, Chile, and Argentina. Other countries, such as Costa Rica, Colombia, Cuba, Peru, Panamá, Paraguay, Trinidad and Tobago, and Uruguay, are following these trends and some others seem to be moving in this direction within the next few years.

Keywords: Health technology assessment, Latin America, History

The Pan American Health Organization (PAHO, World Health Organization [WHO] for the Americas) began to promote health technology assessment (HTA) in the Americas as early as 1983 (under the leadership of Dr. David Banta, Mr. Jorge Peña, and Dr. Gloria Coe) (2). There was a Technology Development Unit from the mid-1980s until the early 1990s that supported some important national and international meetings and consultations $(3 ; 4 ; 8 ; 9)$. In 1998, PAHO published a Regional Strategy for HTA (7). Some studies (assessment) were conducted and published and documents from the Office of Technology Assessment were translated into Spanish and widely disseminated in the region. However, these early activities did not result in any great change in Latin America and the Caribbean policies.

In the mid- to late-1990s, health sector reform became an important movement in Latin America, and PAHO became more active in promoting HTA (under the direct leadership of Dr. Alberto Infante) $(5 ; 6)$. Collaboration of the HTA Agencies from Spain and Canada led to several workshops on HTA and training a critical mass of professionals linked to the decision-making process in Latin America and the Caribbean (225 professionals). Workshops were held in Canada, Mexico, Colombia, Cuba, Panama, Argentina, Chile, and Peru. Several countries, notably Mexico, Brazil, Argentina, Uruguay, and Chile, showed increasing interest in

The author thanks Antonio Hernandez (PAHO) for his assistance with advice and information in the preparation of this article.
HTA. In 1997, MERCOSUR (Argentina, Brazil, Paraguay, and Uruguay economic initiative) organized a Technical Subcommittee on HTA.

In 1998 in the II Summit of the Americas (Head of States and Governments of the Countries of the Americas), Santiago de Chile, April 18-19, the work plan included a chapter on "Health Technology Bridging the Americas." In the year 2000, HTA was included as one of the Essential Public Health Functions in PAHO documents and thinking. PAHO became a member of ISTAHC and promoted the participation of experts from Latin America and the Caribbean in the Annual Meetings. Some academic centers began to carry out HTA studies. PAHO produced some bilingual (English/Spanish) publications on HTA $(5 ; 6)$.

Since 2000, PAHO (under the leadership of Mr. Antonio Hernandez) has redefined the approach to heath technology in the interaction with the countries of the region and has prioritized the strengthening of HTA programs as part of the new approach. PAHO is promoting and supporting the participation of experts in international conferences and training programs (Ulysses and the distant learning course on Health Technology Assessment, AETMIS); collaborating in the organization of HTA Agencies and Centers in the countries; facilitating access to HTA information and databases; and sponsoring internships in HTA. To facilitate the interaction and communication exchange among the experts, a virtual network based on the Internet (Listserv Group hta@listserv.paho.org) was organized in 2004. 
About 2006, as described by Frenk et al. in this volume, Mexico developed a national office of HTA, the National Centre for Excellence in Health Technology (CENETEC) http://www.cenetec.salud.gob.mx/, that has considerable resources and ambitious programs related to health technology assessment and management. Since 2004, an annual international seminar involving mainly Latin American countries has been held in Mexico City under the leadership of the Mexican CENETEC and cosponsored by PAHO.

In Brazil, as described by Banta and Almeida in this issue, a policy toward health technology management was published in 2006, which began to lead to institutionalization of HTA in the national government.

Argentina's approach to HTA, including the use of HTA in insurance coverage decision, is described by Rubenstein et al. in this volume. The Instituto de Efectividad Clínica Sanitaria (IECS) of Argentina http://www.iecs.org.ar/ has developed a training program in HTA.

Cuba has focused on HTA and evidence-based medicine in its health programs in recent years.

Chile developed an office for HTA in its Ministry of Health in 1997 (ETESA - the Unit for Health Technology Assessment, a member of INAHTA). The ETESA is part of the Department of Quality and Patient Safety of the Ministry. Its goal is to generate assessment reports, technical notes, and recommendations based on evidence according to the priorities set by the Ministry of Health.

In Colombia, the Ministry of Social Protection with the PAHO collaboration is organizing a HTA Agency with the active participation of the academic sector.

In Uruguay, the Ministry of Health has an HTA program in the Department of Medical Technology and is active in the MERCOSUR initiative.

In 2001, the Ministry of Health of Trinidad and Tobago initiated a Health Sector Reform movement and gave emphasis to the development of a quality strategy, including the organization of a HTA program. In 2007, the Ministry of Health began to develop an HTA policy framework.

In March 2007, the World Heath Organization, in the 60th World Health Assembly, passed Resolution WHA60.29 on Health Technologies. The resolution urges the Member States to work on health technologies (10).

In 2007, INAHTA, IECS, and CENETEC, with the collaboration of PAHO, conducted a survey to assess the status of HTA in Latin America and the Caribbean and the options for an International Collaboration with INAHTA. The results were presented in HTAi 2008 Meeting in Montreal. Some of the information in this study was taken from that survey.
In HTAi 2008, there was a significant increase in participation from Latin American Countries (Argentina, Brazil, Colombia, Costa Rica, Mexico, Panama, Peru, and Uruguay). The preconference workshop "HTA in Latin America: has the time come for an HTA network?" gave a basis for the organization of a HTA Network in Latin America.

The trend in Latin America seems to be toward increasing activity and interest in HTA $(1 ; 6)$. During the next few years, efforts to institutionalize HTA as part of public health policy will probably be seen in other countries.

\section{CONTACT INFORMATION}

David Banta, MD, MPH (HD.Banta@ orange.fr), 9 route de Bragelogne, 10210 Villiers-de-Bois, France

\section{REFERENCES}

1. Banta D. Medical technology and developing countries: The case of Brazil. Int J Health Serv. 1986;16:363373.

2. Banta D. The uses of modern technologies: Problems and perspectives for industrialized and developing countries. Bull PAHO. 1984;18:139-150.

3. OPS/OMS. Agenda de propuestas de evaluación de tecnologías en programas de salud del adulto. PNSP/85/04/11, Washington, DC: Pan American Health Organization; 1985. (In Spanish only. OPS refer to PAHO in Spanish).

4. OPS/OMS. La cooperación de la OPS ante los procesos reforma sectorial. Washington, DC: Pan American Health Organization; 1997. (in Spanish only).

5. PAHO. Developing health technology assessment in Latin America and the Caribbean. ISBN 927507377 5. Washington, DC: Pan American Health Organization; 1998. (in English and Spanish).

6. PAHO, Health technology assessment in Latin America and the Caribbean: Collection of Cases. ISBN 9275073805. Washington, DC: Pan American Health Organization; 1999. (in English and Spanish).

7. PAHO. Regional strategy for health technology assessment. Washington, DC: Pan American Health Organization; 1998.

8. Panerai R, Pena Mohr J. Health technology assessment, methodologies for developing countries. Washington DC: Pan American Health Organization; 1989.

9. Peña Mohr J, Coe G. Investigación en Tecnología de Salud, OPS; January 1986.

10. World Health Organization. Health technologies. Resolution of the 60th World Health Assembly. WHA60.29. Geneva: WHO; May 2007. 